\title{
Perceptions of pre-service teachers on seismic risk and their implications for science education: a comparative study between Spain and Portugal
}

\section{António Almeida, Beatriz García Fernández \& Isilda Rodrigues}

To cite this article: António Almeida, Beatriz García Fernández \& Isilda Rodrigues (2019):

Perceptions of pre-service teachers on seismic risk and their implications for science education: a comparative study between Spain and Portugal, Journal of Risk Research, DOI: 10.1080/13669877.2019.1617335

To link to this article: https://doi.org/10.1080/13669877.2019.1617335

Published online: 25 May 2019.

Submit your article to this journal $\square$

Џ Article views: 58

a

View related articles

View Crossmark data $₫$ 


\title{
Perceptions of pre-service teachers on seismic risk and their implications for science education: a comparative study between Spain and Portugal
}

\author{
António Almeida ${ }^{a}$ (D), Beatriz García Fernández ${ }^{b}$ (D) and Isilda Rodrigues ${ }^{c}$ \\ ${ }^{a}$ Instituto Politécnico de Lisboa/Interdisciplinary Center of Educational Studies/Research Centre "Didatics \\ and Technology in Education of Trainers", University of Aveiro, Lisboa, Portugal; 'Science Education, \\ Department of Pedagogy, Faculty of Education of Ciudad Real, University of Castilla-La Mancha, Ciudad \\ Real, Spain; 'Department of Education and Psychology, University of Trás-os-Montes e Alto Douro, Vila \\ Real, Portugal
}

\begin{abstract}
This study investigated the importance given by two groups of pre-service teachers of primary education from Spain and Portugal to seismic risk in a framework of different natural risks, both in personal terms and as future teachers. A questionnaire was used for data collection. Some questions about the seismic phenomenon were also included. The sample groups consisted of 110 students from an institution in Spain and 121 from one in Portugal. Both institutions are in cities affected by the historic Lisbon earthquake of 1755 . The results showed that the risk of forest fire was the first choice for classroom study in both cases. The Spanish group was also more focused on the importance of other risks like flood and drought. The Portuguese group showed a greater concern with seismic risk, frequently referring to their own historic earthquake of 1755. A few gaps in knowledge concerning earthquake prediction and comparing seismic risk in different regions of their own countries were also found. In accordance with the results, it is suggested that training courses for primary school teachers should include Disaster Risk Education in Science Education for a better understanding of the impact of various hazards and a greater concern with seismic risk due to its particular features, especially in regions where the seismic pattern is characterized by long seismic cycles with major earthquake episodes.
\end{abstract}

\section{ARTICLE HISTORY}

Received 4 June 2018

Accepted 4 March 2019

\section{KEYWORDS}

Science education; disaster risk education; seismic risk; historical earthquakes; primary education; teacher training

\section{Introduction}

Natural risks are a main issue to be considered in Education (Muttarak and Lutz 2014), especially on the Science Education curriculum, as it implies knowledge of the functioning of the Earth and prepares citizens for these events (National Research Council 2013). These contents are usually included in the field of Disaster Risk Education and its aims are to increase awareness of the effects and causes of different disasters, to contribute to a culture of prevention, and, consequently, to help protect children, among the most vulnerable members of our societies.

CONTACT António Almeida aalmeida@eselx.ipl.pt $=$ Instituto Politécnico de Lisboa/Interdisciplinary Center of Educational Studies/Interdisciplinary Center of Educational Studies - Campus de Benfica do IPL, Lisboa, Portugal/Research Centre "Didatics and Technology in Education of Trainers", University of Aveiro, Lisboa, Portugal 


\section{The approach to natural risks in Portugal and Spain}

The curricula for primary education in Spain and Portugal address the issue of natural risk (e.g. earthquake, flood, or fire) and technological risk (e.g. transportation of hazardous materials, or biological and chemical threats) in a different way. In Spain, in the Real Decreto 126/2014 de Enseñanzas Mínimas (The Royal Decree for Minimum teaching requirements) published in 2014 in the LOMCE Education Law (2013), the different risks, emergencies and catastrophes are mentioned in the cross-curricular areas, besides as well as the need for coverage of risk in the Science area, but without any specification of the natural risks that should be addressed. In Portugal, there is only a very brief reference on the primary school curriculum to the need to be aware of, and to apply rules for the prevention of forest fires and earthquakes in similar curricular areas (Ministério da Educação 2004). However, in 2015, a complementary document entitled 'Referencial de Educação para o Risco' (Guidelines for Disaster Risk Education) by Saúde et al. (2015) was published by the Ministry of Education to help teachers to address different natural and technological risks, including the expected learning outcomes for each one. In this document, almost all the main risks of both types are included, like landslide, flood, earthquake, forest fire, drought or storm and accidents in the transport of dangerous goods, collapse of structures or industrial accidents. Besides, there is also a reference to the mixed nature of certain risks, as well as a recommendation that this issue be covered in the cross-curricular area called Education for Citizenship.

Despite the differences noted in the guidelines in the two countries, the situation is ultimately very similar. If in Spain the document is characterized by a lack of clarification of the risks to be addressed, in Portugal the new document has a non-mandatory statute and its publication was not accompanied by any teacher training components and was also poorly publicized.

Indeed, a way to draw attention to Disaster Risk Education in both countries could be through teacher training. But pre-service teacher training courses, at least in the institutions involved in the present study, pay little attention, if any, to this issue, either in curricular units related to Science or in those more focused on educational content, as is readily apparent when checking the syllabus of different curricular units. The inattention to Disaster Risk Education is also incomprehensible, considering the research already available concerning the issue and the recommendations of different experts. For instance, Panić et al. (2013) state that education is essential for building a culture of prevention and resilience, in order to mitigate the consequences of natural disasters. And several studies published prior to these procedural guidelines concluded that scientific information, together with knowing what action to take, result in a decrease in numbers of casualties, since they help children to recognize the signs of imminent disasters (see, e.g. King and Gurtner 2005; Morrissey 2007; Muttarak and Lutz 2014), all reasons that explain why highly-educated individuals are better prepared to deal with disasters.

In this negative global scenario, the National Authorities for Civil Protection in both countries have been actively working to make teaching materials and resources available to schools. However, the question remains whether these efforts are sufficient to put the issue on the school agenda, considering the absence of mandatory guidelines as to how to approach different types of risks.

\section{Seismic risk and the main aims of the study}

Even knowing that an approach to the different risks in formal education is essential, special attention should be given by teachers to seismic risk due to its nature: less regular frequency comparing with other risks but a very dangerous impact due to the unpredictability of the phenomenon. In certain regions of the earth, even with a quite different tectonic framing, the seismic pattern is similar: a medium to high seismic risk with a long period of low seismicity interrupted by major earthquakes $(M>7.5)$. With particularities, this is the case of the 

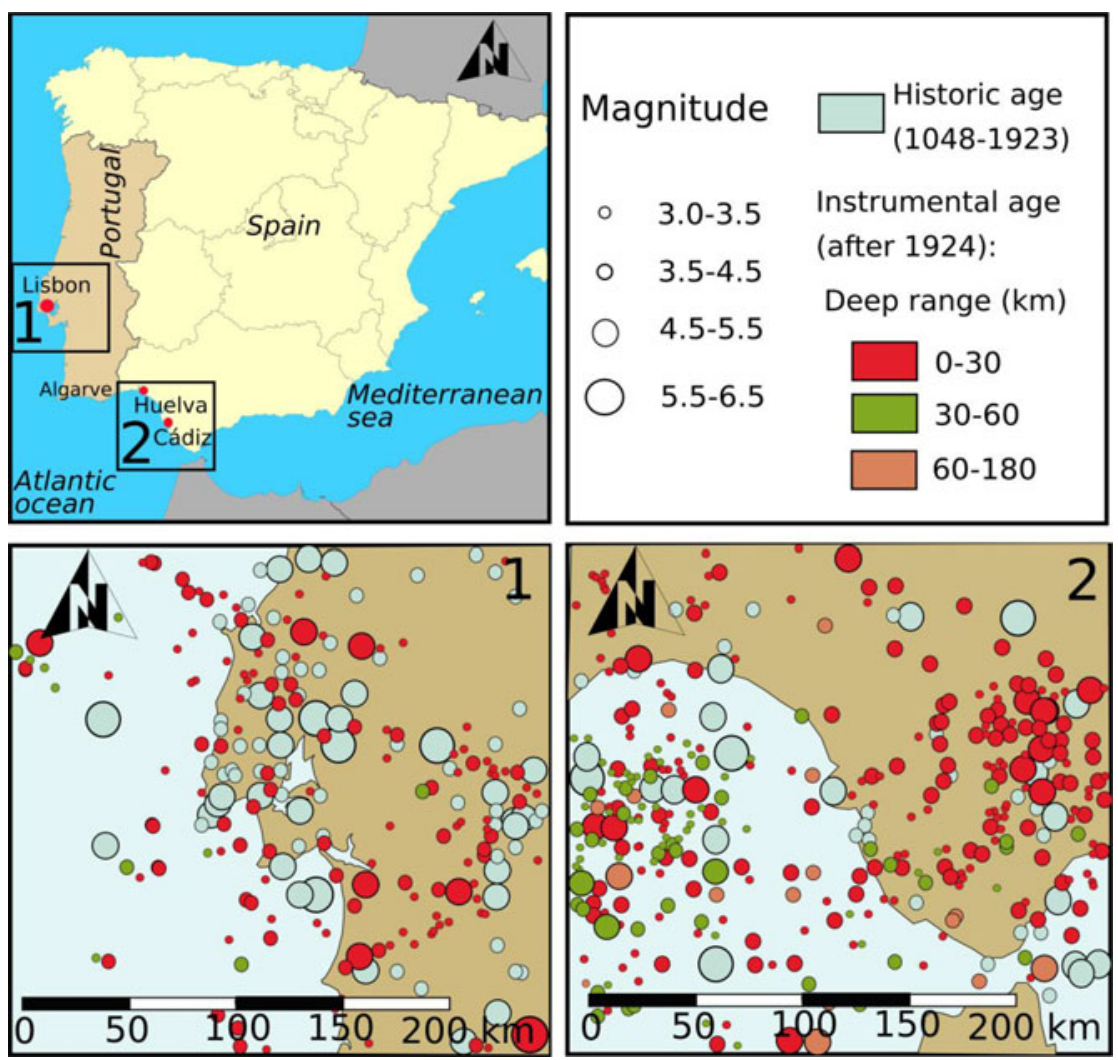

Figure 1. Historic seismic activity in Lisbon and Cádiz-Huelva region. Source: Designed by the authors based on data from the Instituto Geográfico Nacional (2015).

Mediterranean region from Iran to the Azores archipelago (Purcaru and Berckhemer 1982), the Greater San Francisco Bay region (Bufe and Varnes 1993) or the Himalayan mountain system (Avouac 2003).

Therefore, in the Mediterranean region, Portugal and Spain have a tectonic framing that justifies special attention to seismic risk. The Iberian Peninsula is part of the Eurasian plate in its collision with the African plate. The boundary between the two plates is tectonically less active in the western part when compared to other segments in the eastern part (Téllez Alarcia 2007). Even so, The Gulf of Cadiz, included in the Azores-Gibraltar boundary, is a potential source of high magnitude earthquakes and tsunamis that can affect especially southwestern Spain, south Portugal, and northern Morocco (Matias et al. 2013; Campos Romero 1992). But the seismicity in all this area can be considered of moderate magnitude and shallow to intermediate depth, with a history of small earthquakes $(M<5.0)$ to extreme ones $(5.0<M<7.8)$, occurring in long seismic cycles (Silva et al. 2010). Figure 1 includes the historic seismic activity in the Lisbon and Cádiz-Huelva region.

One of these extreme events was the well-known Lisbon earthquake which occurred on 1 November 1755. With a magnitude of 8.5-9.0, it affected several areas of the above-mentioned countries, and persists in the collective memory of Portugal and Spain at least in the research community (Campos Romero 1992). A good example of this persistence is the publishing of fresh articles in the last two decades trying to bring new insights to the seismotectonics of the area or to discuss the impact of the earthquake in Lisbon, Algarve, Huelva or Cádiz (see, e.g. Carreño Herrero 2005; Silva et al. 2010; Lima et al. 2010; Matias et al. 2013).

The periodicity of extreme earthquakes is uncertain due to the geological complexity of the area. Matias et al. (2013) state that these cycles could be of over 1000 years, a possibility that is 
far from being consensual. In fact, the historical records of earthquake activity only extend back, in the best cases, a few hundred years, a period which is not enough to understand a particular seismic cycle (Hays 2004). The most important earthquake in the last decades was the one that occurred on 28 February 1969, felt in Lisbon, the Algarve and Huelva (Miranda and Carrilho n.d.; Téllez Alarcia 2007), causing material damage and a few casualties.

Yet, despite these events and a general history of seismic activity, the seismic pattern described may be the reason for a general lack of concern about future earthquakes within the population. In fact, risk perception is related to how each person assesses as risky a particular object or event (Garder and Jones 2011). And it is a very complex issue that does not deal only with knowledge or the number of deaths it causes (Slovic 2001; Lima 2005). Other dimensions related to its acceptability, like its nature (natural or artificial) and our capacity to control it, have an important role in this perception (Sagoff 1992). Even the extent of coverage given to the different risks in the media can influence people's perceptions (Lima 2008).

A study by Tavares, Mendes, and Bastos (2011), carried out in Portugal with a nationwide sample of 1200 individuals over 17 years old, confirms that risk perception showed that participants had a very low awareness of a variety of natural risks. In the case of seismic risk, in particular, this perception was even lower if compared to other natural hazards like storm, forest fire, heat wave and extreme cold, flood and landslide. The perception of the risk of tsunami was even lower than the seismic, although a little higher among the participants from Lisbon and the Algarve. In fact, the study showed a few differences between the respondents from the coastline, more worried about storm, and those from the hinterland, more worried about drought. The respondents with more than nine years of schooling also revealed a little higher perception of the different risks, including the seismic. A study by Birkmann et al. (2011) with respondents from Cádiz, one of the cities in Spain most affected by the 1755 earthquake and the tsunami it generated (Campos Romero 1992), also revealed a similar result concerning the lower perception of seismic risk.

Therefore, the present research aims:

1. to check the importance given by pre-service teachers of primary education from both countries, Spain and Portugal, to seismic risk among the various natural hazards, both in personal terms and those of their future teaching practice, knowing that their institutions and residences are in areas where major earthquakes can occur;

2. to assess the general knowledge about seismic phenomena of these pre-service teachers;

3. to identify differences between the two groups knowing that, besides the similarities, each country has its own agenda concerning a variety of educational issues.

The conclusions of the present research may be important for the design of future teacher training courses, and may help to focus the research community and teachers from non-higher education institutions on Science and Disaster Risk Education in general and on seismic risk in particular.

In fact, Gulay (2010) also argues that the inclusion of the approach to this risk is essential, due to the age of the children, their vulnerability and also because of their difficulties in perceiving the specificities of earthquakes as a phenomenon beyond our control. In fact, children are more vulnerable to disasters than adults, since they have less physical strength and less ability to escape (Yeh 2010). And beyond the vulnerability of children to seismic risk, some disasters, including earthquakes, can happen during the school period (Hosseini and Izadkhah 2006); and more positively, children can be agents of change due to their capacity to transmit a culture of prevention to their families (Shiwaku 2009; Saúde, et al. 2015). Therefore, to paraphrase Shaw et al., 'Children who have been taught about the phenomenon of disasters and how to react to those situations have proved to be able to respond promptly and appropriately, thereby warning others and protecting themselves during times of emergencies' $(2001,1)$. 


\section{Methods}

This study aims to contribute to a better understanding of pre-service teachers' perceptions about Disaster Risk Education in primary school. The study has a predominantly quantitative approach, but some data were treated qualitatively, as will be seen below.

\section{Participants}

The study involved a sample of 231 pre-service teachers in their fourth year of higher training; 110 students (70 women and 40 men) from a Spanish university, in the academic year 2016/ 2017 and 121 (117 women and 4 men) from a Portuguese higher education institution, in the academic years 2015/2016 and 2016/2017. We tried to include in the research all the students admitted by both institutions in the above-mentioned academic years, and the reason to include students from two academic years at the Portuguese Institution was due to the fewer vacancies available per year.

The average age of the students from both groups was $22.5(S D=1.935)$ in the Spanish group and $21.9(S D=2.223)$ in the Portuguese. Both institutions are involved in training courses for teachers of the first six years of Primary School (children aged from 6 to 12).

The institutions were chosen based on the characteristics of the seismicity of both countries, as outlined previously. Accordingly, both institutions are in cities where seismic risk is considered moderate to high, and which were affected historically by extreme events (earthquakes and tsunamis). In both countries the students live near the teaching institutions (less than $30 \mathrm{~km}$ ), a very frequent situation in Spain and Portugal due to the nature of the school network.

Primary school teachers have a very broad training, from Science to Mother Tongue, and teacher training courses must respond to this diversity of subjects. The main consequence is that certain subjects cannot be treated in depth, if at all. Even so, some general Earth Science knowledge is addressed in both institutions concerning several issues of the internal and external geodynamics of the planet. But the syllabus where this content is included does not specify regional situations and it excludes any reference to Disaster Risk Education.

\section{Procedure}

To meet the aims of the research, a two-part questionnaire was designed ad hoc. After indicating some personal information, age, gender, and residence, in the first part the participants were invited to select two natural hazards from a choice of eight based on their personal interests; they then repeated the selection of two risks based on their relevance to children. The eight natural risks included were: landslide, flood, earthquake, forest fire, volcanic activity, drought, storm and coastal erosion. This selection emerged from an analysis of various Internet sites related to Civil Protection in Spain and Portugal (IGN 2017; Protección Civil Spain 2013; Proteção Civil Portugal 2010), and in the case of Portugal these natural risks are also included in the Disaster Risk Education Reference already quoted. In the second part, the questions tried to assess some general knowledge of the participants about seismic phenomena. Due to the focus of the second part, it was only given to the respondents after completion of the first, so as not to focus attention on seismic risk. The survey questions are included in Table 1.

The questionnaires were administered by two different persons, one in Spain and another in Portugal. Completion of the questionnaire took 30 minutes on average, and no difficulties were identified. The different types of data collected, choice of risks, reasons for that choice and knowledge about seismic risk, have been triangulated. 
Table 1. Structure of the questionnaire presented to the students from both institutions.

Part I

1. Of the following risks - landslide, flood, earthquake, forest fire, volcanic activity, drought and storm - indicate which two personally concern you the most. Justify your answer.

2. Of the following risks - landslide, flood, earthquake, forest fire, volcanic activity, drought and storm - indicate which two you consider to be the most important in your work with students? Justify your answer.

Part II

1. In general, how do you assess seismic risk in Spain / Portugal? Low, Medium or High.

2. Do you believe that there are areas in Spain / Portugal with greater seismic risk than others? Yes or No? If Yes, indicate which.

3. Have you ever experienced an earthquake? Yes or No? If Yes, how did you react?

4. Can you recall any earthquakes that occurred in Spain / Portugal? Yes or No? If Yes, indicate which.

5. Can you recall any earthquakes that occurred internationally? Yes or No? If Yes, indicate which.

6. Do you believe that scientists can accurately predict the date an earthquake will occur in a particular region of Portugal / Spain? Yes or No? Explain.

\section{Treatment of replies}

A chi-square test was used to test for homogeneity between the answers of the pre-service teachers of both groups (Portugal and Spain), and the level of significance was set at $p<0.05$.

Since the first part of the questionnaire asked respondents to select two risks for each of the questions, it was considered that any risk could be equally selected at the outset. Thus, each risk was considered in isolation, being assigned a value of 'one' when the respondent chose it and 'zero' when it was not chosen. In the second part of the questionnaire the same statistic test was used to compare the frequency of responses involving a choice between yes and no, with the exception of Question 1, for which the selection was among three options related to the evaluation of seismic risk. With regard to the justifications and other open questions, a content analysis was conducted to categorize the ideas presented, and their frequency estimated. Responses were entered in the following five categories, which were obtained a posteriori: risk management, risk causes, risk consequences, risk occurrences and educational and didactic aspects. This last category was only found in the answers justifying the relevance of the risks to the respondents' future teaching activity.

\section{Validation}

The instrument was validated prior to the administration of the sample considered in the present article. Content validity and reliability were considered in order to validate the instrument. First, the validity of the questionnaire was determined by an expert panel comprised of four experts in Science Education, two of them specialists in Geology Education. This phase of validation confirmed the suitability and accuracy of the questions, the relevance and pertinence of the information given by each one, and the clarity, length and ease of application.

Second, the questionnaire was also administrated to a sample of 77 pre-service teachers from another institution not included in the final sample. The results of this prior test confirmed that the questions in the test did not allow ambiguous answers, and the suitability and accuracy of the items, their clarity and ease of application. No errors were identified to justify any modification.

Finally, the reliability of the instrument was determined by applying the test-retest procedure, to verify if the test had the ability to produce consistent results when the same entities are tested at two different points in time. To this end, the questionnaire was administered twice to 50 pre-service teachers, with fifteen days between the first and the second application. This time lapse was determined by the fact that reliability is considered as the ability of a measure to produce consistent results over time (Field 2009), so that the administration two weeks after the first application is recommended (Levy and Goldstein 1984) to verify that answers are consistent over time. After both administrations of the questionnaire, the test-retest reliability intraclass 
correlation coefficient was calculated. The value obtained, 0.778 , indicated a good reliability of the instrument.

We can therefore conclude that the test designed is valid and reliable to be used as an instrument for data collection.

The responses to the open questions were analyzed and categorized by three team members separately and, afterwards, the categories assigned by each of the three were discussed in group. A final analysis took place to eliminate any possible discrepancies in categorization, also involving two members of the expert panel.

\section{Results}

The results are presented according to the two parts of the questionnaire.

\section{Part 1}

With regard to the question that inquired about the risks that were of greatest concern in personal terms (Table 2), respondents from Spain (first group) selected the following top three disasters: fire (50.9\%), flood (40.0\%) and earthquake (38.2\%); and those from Portugal (second group): earthquake (58.7\%), fire $(57.0 \%)$, drought $(21.5 \%)$ and storm (21.5\%). Although seismic risk was among those chosen in both groups, it was much more common in the second group and this led to a statistically significant difference $(p=0.002)$. Other statistically significant differences $(p<0.05)$ were related to drought and flood, selected with a higher incidence in the Spanish group, and landslides, almost entirely selected by the Portuguese group.

With reference to the risk that respondents considered most relevant to address as teachers (Table 2), both groups selected fire as their first choice $(79.3 \%$ for the Portuguese and $79.1 \%$ for the Spanish). The Spanish group selected drought as their second choice with a much higher frequency $(59.1 \%)$, and differences between the two groups were statistically significant $(p=0.001)$. Earthquake was the second choice of the Portuguese group with a much higher incidence $(66.9 \%)$, and the differences between the two groups were also statistically significant $(p=0.001)$. The third risk most widely selected was earthquake for the Spanish group and volcanic activity for the Portuguese contingent but with a much lower frequency $(20.9 \%$ and $10.7 \%$ respectively). Even so, an especially in the case of the Portuguese sample, the seismic perception of the participants was greater when compared with the results of the Portuguese national study designed by Tavares, Mendes, and Bastos (2011) presented in the Introduction. The difference may be related to the sample used in the present study, which is composed exclusively of primary pre-service teachers.

Table 2. Selection of risks by personal choice and their relevance to children in both groups, the first from Spain and the second from Portugal.

\begin{tabular}{|c|c|c|c|c|c|c|c|c|c|c|c|c|c|c|}
\hline & \multicolumn{6}{|c|}{ Personal choice } & \multirow[b]{3}{*}{$p$} & \multicolumn{6}{|c|}{ Relevance for children } & \multirow[b]{3}{*}{$p$} \\
\hline & \multicolumn{3}{|c|}{ First group } & \multicolumn{3}{|c|}{ Second group } & & \multicolumn{3}{|c|}{ First group } & \multicolumn{3}{|c|}{ Second group } & \\
\hline & Freq. & $\%$ & $r$ & Freq. & $\%$ & $r$ & & Freq. & $\%$ & $r$ & Freq. & $\%$ & $r$ & \\
\hline Landslide & 2 & 1.8 & 8 & 10 & 8.3 & 7 & 0.027 & 1 & 0.9 & 8 & 11 & 9.1 & 5 & 0.050 \\
\hline Flood & 44 & 40.0 & 2 & 20 & 16.5 & 5 & 0.001 & 13 & 11.8 & 5 & 8 & 6.6 & 8 & 0.169 \\
\hline Earthquake & 42 & 38.2 & 3 & 71 & 58.7 & 1 & 0.002 & 23 & 20.9 & 3 & 81 & 66.9 & 2 & 0.001 \\
\hline Fire & 56 & 50.9 & 1 & 69 & 57.0 & 2 & 0.352 & 87 & 79.1 & 1 & 96 & 79.3 & 1 & 0.963 \\
\hline Volcanic activity & 13 & 11.8 & 6 & 9 & 7.4 & 8 & 0.257 & 8 & 7.3 & 6 & 13 & 10.7 & 3 & 0.359 \\
\hline Drought & 40 & 36.4 & 4 & 26 & 21.5 & 3 & 0.012 & 65 & 59.1 & 2 & 11 & 9.1 & 5 & 0.001 \\
\hline Storm & 15 & 13.6 & 5 & 26 & 21.5 & 3 & 0.119 & 15 & 13.6 & 4 & 12 & 9.9 & 4 & 0.380 \\
\hline Coastal erosion & 8 & 7.3 & 7 & 11 & 9.1 & 6 & 0.615 & 8 & 7.3 & 6 & 10 & 8.3 & 7 & 0.779 \\
\hline
\end{tabular}

Freq., frequency; $r$, rank; $p$, probability. 
For both the above-mentioned choices, the reasons were grouped into the five categories previously presented.

An analysis of the reasons given by respondents from both groups related to their personal interest (Table 3) shows that the most widely chosen risk, forest fire, was motivated mainly by its effects $(59-53.6 \%$ in the first group and $38-31.4 \%$ in the second) and by rate of occurrence (31-28.2\% in the first group and $26-21.5 \%$ in the second). Seismic risk, the main focus of the present article, was selected for its effects $(49-44.5 \%$ in the first group and $32-26.5 \%$ in the second) but also for its management (10-9.1\% in the first group and $20-16.5 \%$ in the second). The main difference between the two groups is a much higher incidence of personal anxiety towards flood and drought in the Spanish group, motivated, respectively, by the probability of occurring in the places where the participants live and for their impact on the environment.

Regarding the appropriateness of presenting different risks to children, Table 4 shows that forest fire was again the most selected risk, motivated mainly for its management $(60-54.5 \%$ in the first group and $53-43.8 \%$ in the second) and for its educational or didactic aspects (39-35.5\% in the first group and $15-12.4 \%$ in the second) especially to raise awareness of environmental protection and resources. The main differences between the two groups also revealed a much higher selection of drought in the Spanish group due to the need to raise children's awareness of this problem, and of earthquake in the Portuguese group to increase prevention and how to act.

Since it would be too exhaustive to highlight all the relevant data obtained, other respondent reactions to the different risks can be found in Tables 3 and 4 .

\section{Part 2}

The second part of the questionnaire included questions that aimed to test general knowledge of seismic phenomena.

Seismic risk is perceived by most respondents, 55 (49.5\%) in the first group and 56 (50.5\%) in the second, as being moderate, and the differences between groups are not statistically significant $(p=0.692)$. The majority of respondents also recognize that seismic risk in Spain and Portugal is not the same throughout the territory, with $88(80 \%)$ in the first group and with 101 (83.5\%) of the second group emphasizing this idea, a difference that is not statistically significant $(p=0.495)$.

The regions that the respondents indicated as being most vulnerable to seismic risk were almost always in the south of the two countries. This was mentioned in different ways by the respondents of the first group, indicating the Atlantic coast, the coast of Andalusia or the South of Spain; the respondents of the second group also referred to the south of Portugal, but the majority of the answers indicated Lisbon and the Tagus Valley and also the coast. In this case, only a few stressed that it was particularly the coastal area from the centre to the south of the country. Almost $20 \%$ of the Spanish group and $10 \%$ of the Portuguese gave some vague responses referring to areas of the country affected by tectonic faults without mentioning which ones. Also, $10 \%$ of the respondents from each country did not indicate any zone. To a better assessment of the responses of the participants to this question, please check the map of the areas mostly exposed to seismic risk in the Iberian Peninsula (Figure 2).

Considering now the question that aimed to check whether the respondents had already felt an earthquake and their behaviour manifested during its occurrence, the results show very little contact with the phenomenon: $80(72.2 \%)$ of the respondents from Spain and 75 (62\%) from Portugal had never experienced an earthquake, a difference that also remains statistically nonsignificant $(p=0.083)$. Those who had felt an earthquake remained calm, a behaviour that was certainly helped by its small magnitude, and even a few also confessed that the perception of the earthquake was only totally understood after hearing of the occurrence through the media. 


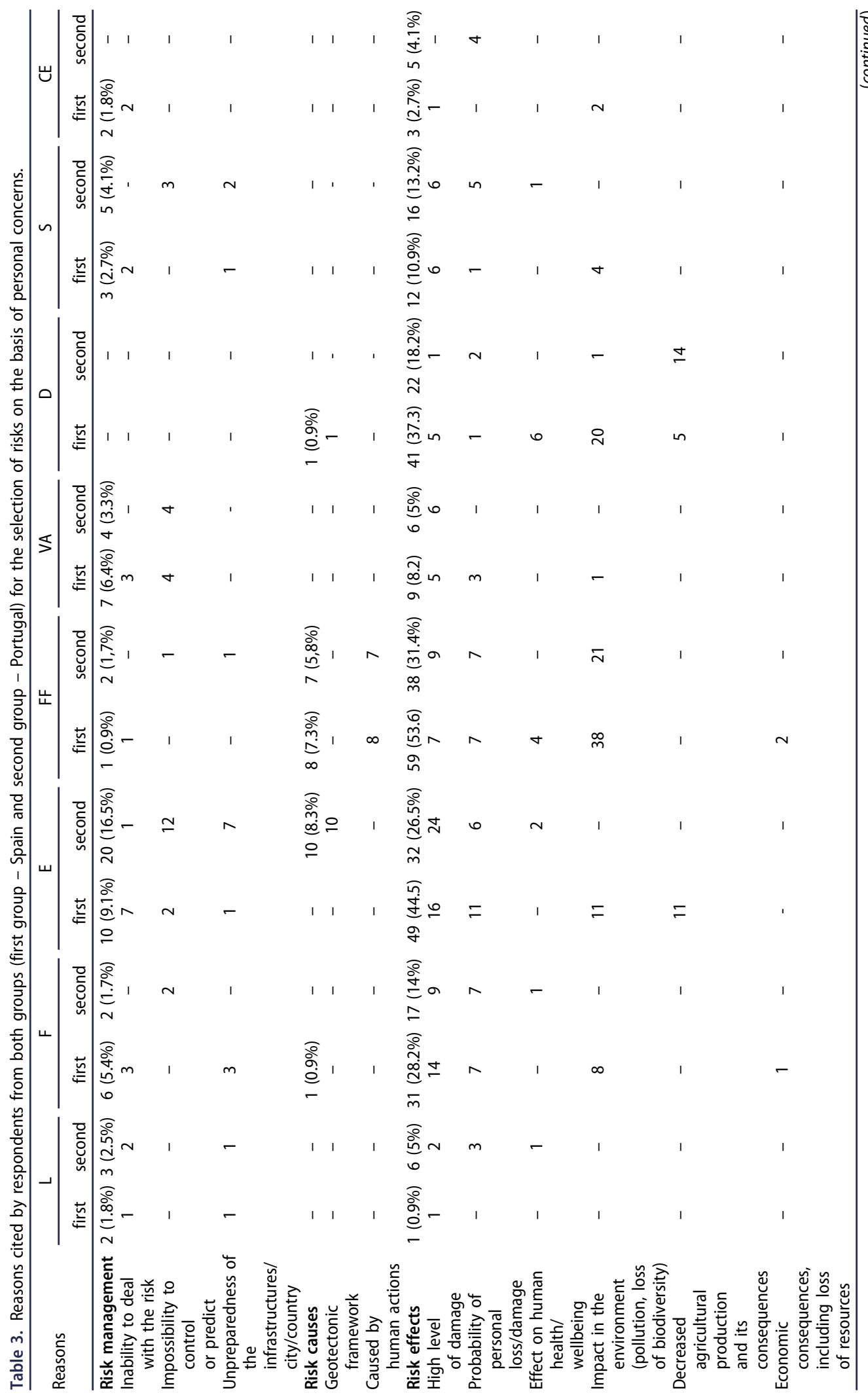




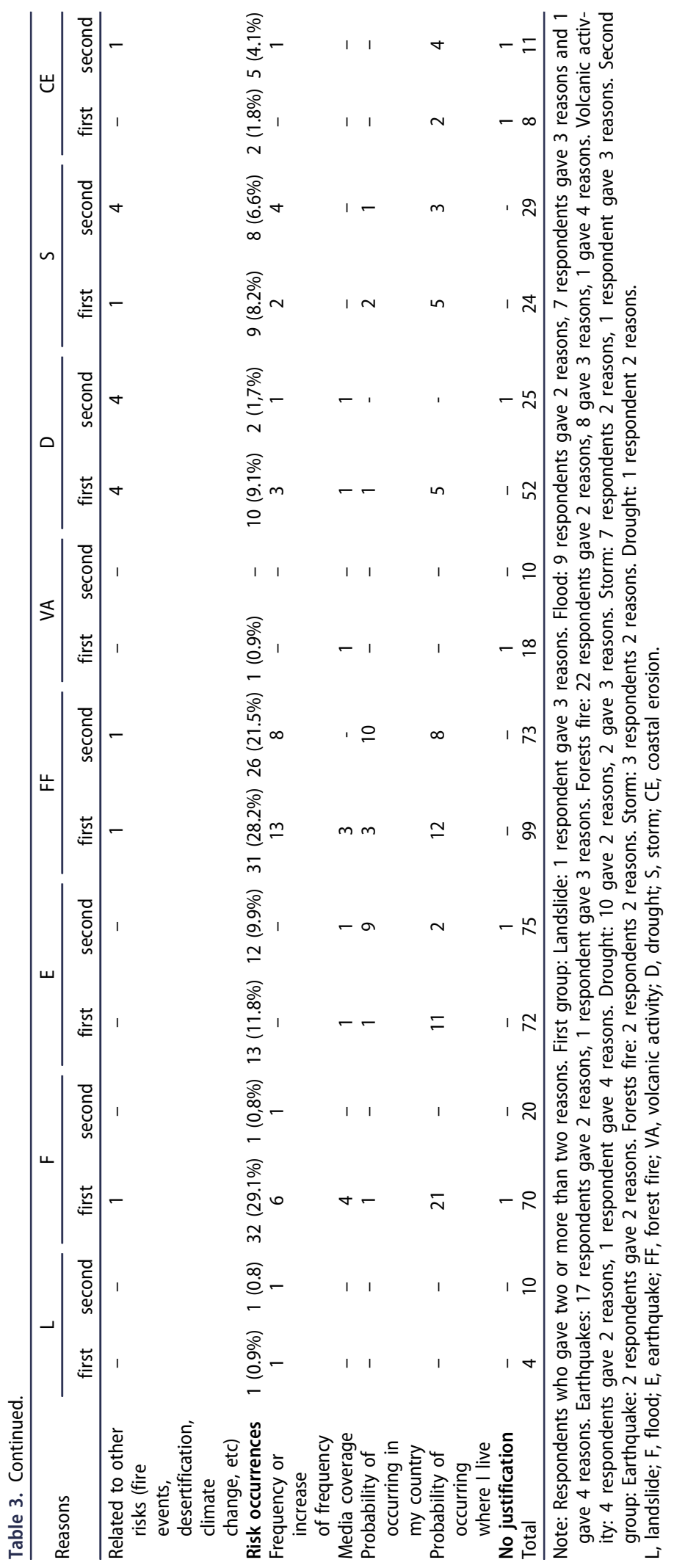




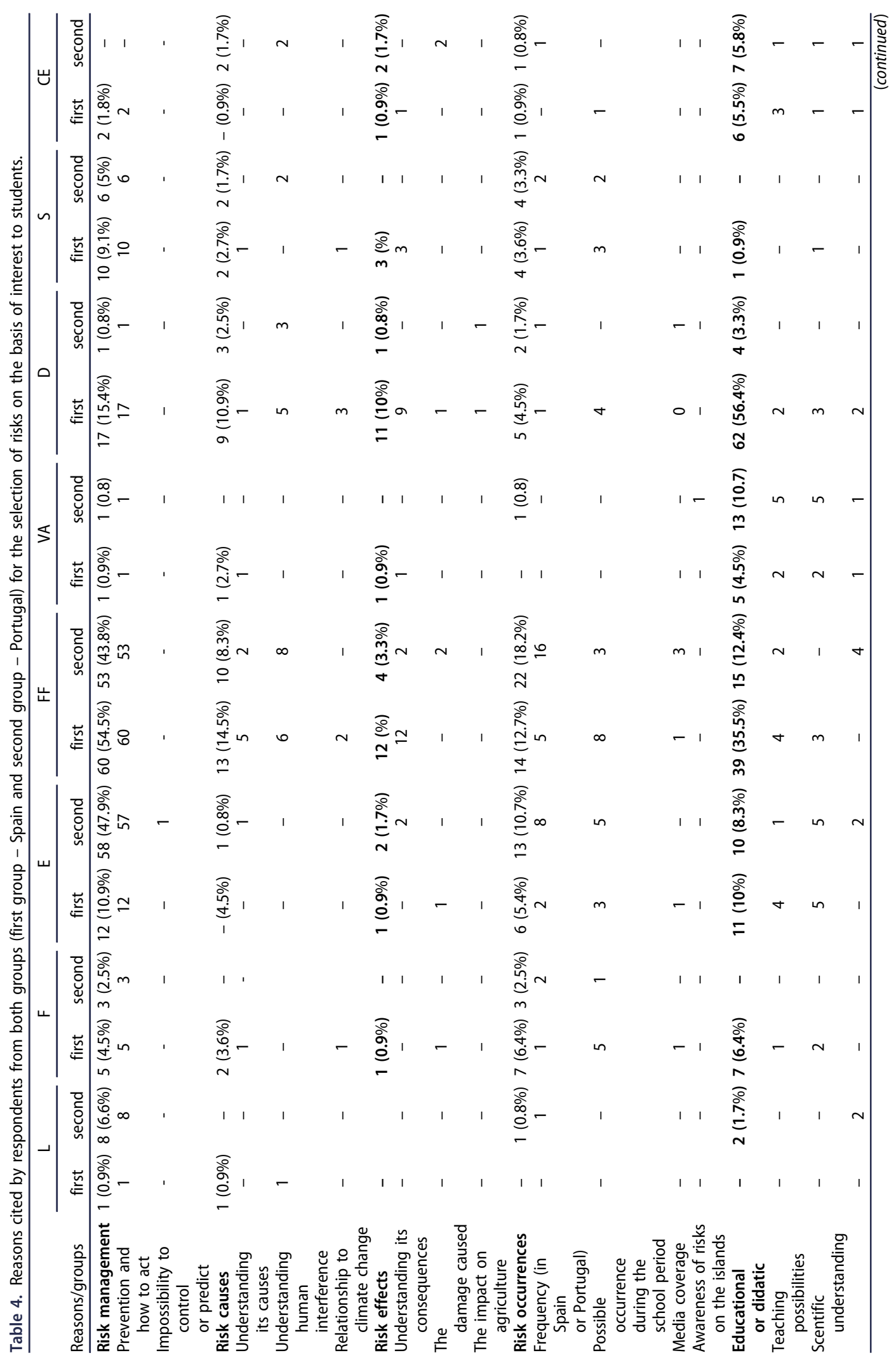




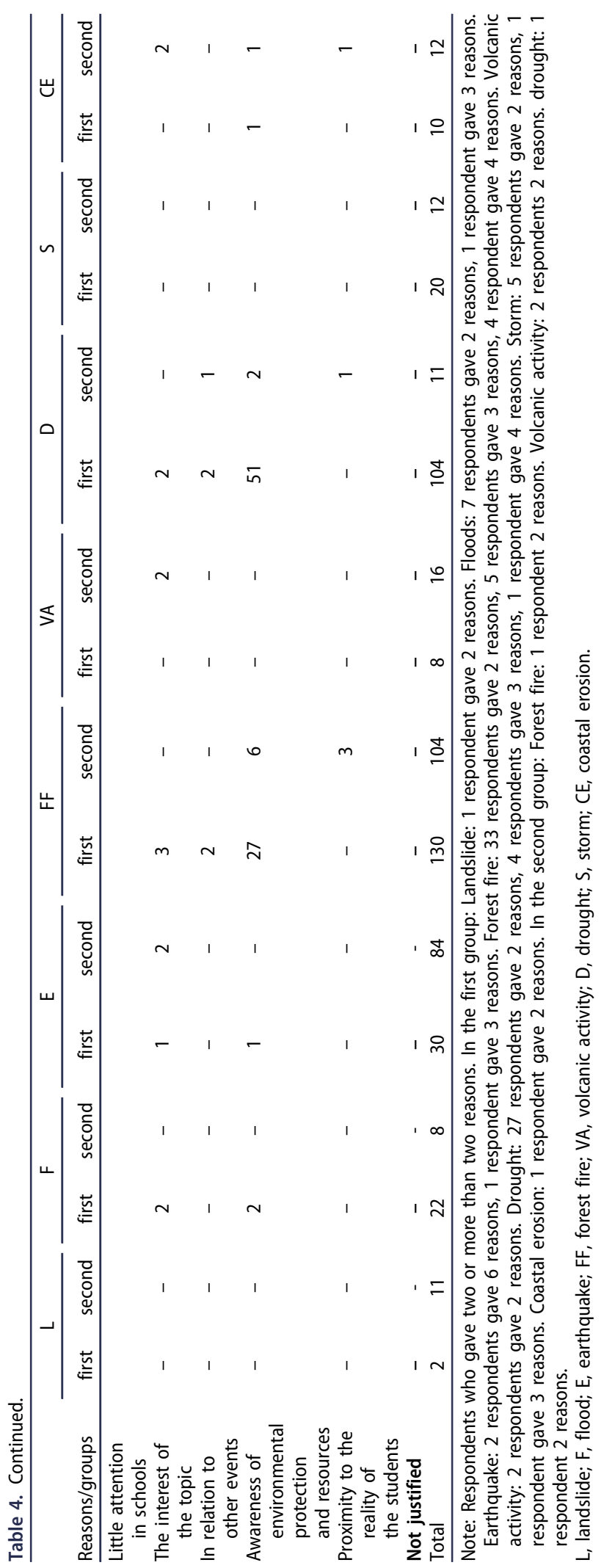




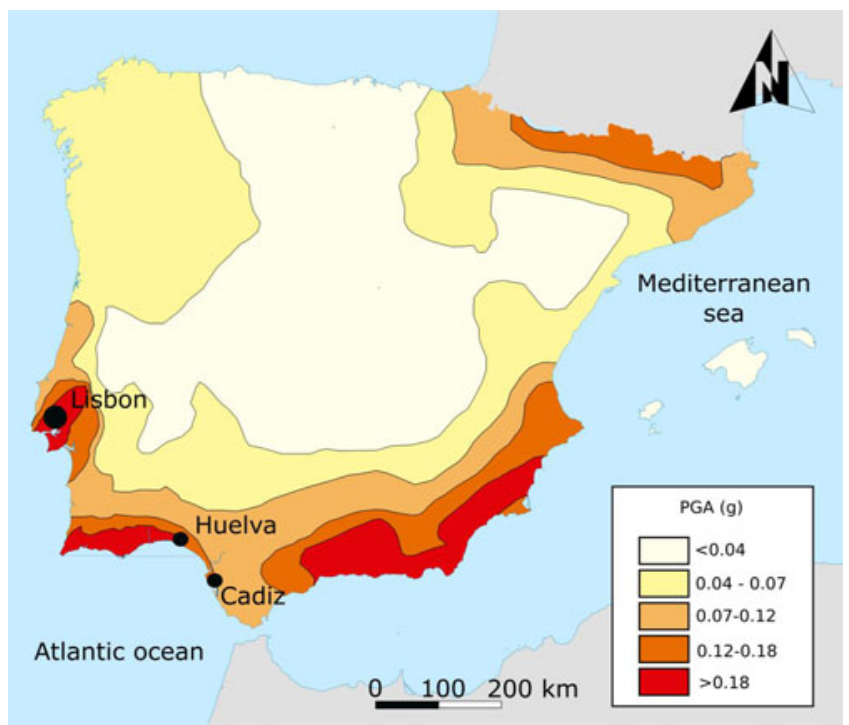

Figure 2. Map of seismic hazard in the Iberian Peninsula. Source: Designed by the authors based on data from Burton and Silva (2014) and from the Instituto Geográfico Nacional (2015).

Table 5. Positioning of respondents from both groups regarding the possibility of predicting earthquakes (first group: Spanish pre-service teachers; second group: Portuguese pre-service teachers).

\begin{tabular}{lcc}
\hline & First group & Second group \\
\hline No & 76 (69.1\%) & 102 (84.3\%) \\
Since there is not enough technology (instruments) & 7 \\
It is impossible to predict an exact date & 33 & 40 \\
Otherwise a lot of damage could be avoided & - & 4 \\
Since nature (or tectonic dynamics) is unpredictable & 23 & 24 \\
Because earthquakes are complex phenomena & 2 & 4 \\
Only zones with more seismic risk can be predicted & 1 & 5 \\
It can be predicted based on changes in the weather, but without a precise date & 0 & 1 \\
Since I never heard an earthquake announced in advance & & 1 \\
No justification given & 8 & 9 \\
Yes & $34(30.9 \%)$ & $15(15.7 \%)$ \\
With the help of technology (instruments) & 4 & 7 \\
By using seismographs & 14 & 5 \\
Based on studies already made & 0 & 1 \\
But only with little notice & 1 & 5 \\
ln areas with high seismic risk & - & 1 \\
No justification given & & - \\
\hline
\end{tabular}

Equally unsurprising was the absence of references to specific earthquakes in both territories. In the Spanish group, 67 (60.9\%) respondents claimed to have knowledge of an earthquake, a number that was higher in the Portuguese group, 97 (80.2\%), a difference that is statistically significant $(p=0.001)$. However, several respondents had some difficulty pinpointing a particular event, mentioning vaguely one occurrence a few years ago or affirming that they didnt remember. Even so, the respondents from the first group recalled events in Murcia, Cádiz and the Coast of Andalusia. The great earthquake of 1755 was the one that received the highest number of references in the Portuguese group, $51(42.1 \%)$, and only $5(4.5 \%)$ of the respondents of the Spanish group chose this event, even knowing that it had an important impact on Spain. On the contrary, $85(77.3 \%)$ of the respondents from the first group and 103 (85.1\%) from the second recall earthquakes that occurred internationally, a difference between the two groups not 
statistically significant $(p=0.126)$, with references to recent seismic episodes in Haiti, Japan, Italy, Indonesia or Chile.

Finally, the last question was related to earthquake predictability (Table 5) and, based on the explanations given, some erroneous conceptions were identified.

The majority of respondents from both groups considered that it is impossible to forecast earthquakes, an answer that occurred in 76 (69.1\%) participants of the Spanish group and 102 (84.3\%) of the Portuguese. However, due to the fact that this answer was much more frequent in the second group, the differences are statistically significant $(p=0.006)$. The main reasons were precisely the impossibility of predicting exact data and also the fact that nature, or tectonic dynamics, is unpredictable. Those that believe in the predictability of the seismic phenomenon based their erroneous opinions on existing technology and on studies already available, and a few of them highlighted the possibility of knowing 'where' and 'when' it can happen. Some participants also think that seismographs are instruments able to predict earthquakes.

\section{Discussion}

The present study shows that the risks most widely selected by pre-service teachers are the most frequent in recent years and that cause a wide range of negative effects, a selection that was even more evident in the Spanish group. In fact, if the seismic phenomenon is responsible for material damage and a large number of people being killed, the impact of drought and flood is even higher at a global and national level (Wisner et al. 2004; Tavares, Mendes, and Bastos 2011). Thus, the results also seem to be related to the negative impact of these natural disasters in the south of Spain in the last decade. For instance, just a few months before the setting of the questionnaire to the Spanish group a torrential rainstorm struck in the region, an event that seems to have influenced the risk selection of these participants. Flood, drought, and forest fire are also risks which are related to climate change (Gregario 2010), a phenomenon responsible for their increase in frequency and intensity. Climate change also allows the perception that natural risks are, increasingly, the result of human activity (Dupuy 2006; Aragão 2011), but only a few respondents from the two countries established this relationship.

Even so, the Portuguese group selected seismic risk with a higher frequency, both in personal terms, their first choice, and in terms of its relevance to children, their second choice. This could be related to historical features and even architectural elements, with which the people of Lisbon are in permanent contact and which can help to keep the historical Lisbon earthquake in the Portuguese memory. The rebuilding of Lisbon, with its geometrically planned pattern known as the Pombaline downtown is a landmark in Portuguese History, covered in the curriculum in different cycles of schooling and ever present in the daily lives of those who live in the Lisbon area. And one of the biggest statues in Lisbon is the one of Marquis of Pombal, the Prime Minister of Joseph I, King of Portugal, who ordered the rebuilding of the city. Another landmark is the pioneer earthquake-proof system called the Pombaline cage used in the construction of the new buildings (Maxwell 2005), which is always remembered in any discussion in Portugal concerning earthquakes. Also important are the idiomatic expressions in the Portuguese language, still popular nowadays, based on events related to the earthquake.

However, the Portuguese group also selected forest fires as the most important risk to be addressed with children, a selection that was coincident with the Spanish group. This fact is undoubtedly related to the numerous instances of this tragic occurrence to devastate parts of the Iberian Peninsula every year.

In general, it is possible to state that the results validate, if only partially, the opinion of Gonçalves (2004) that the low frequency of major earthquakes can devalue the social perception of the danger and the priority of this phenomenon on policy makers' agendas. It shows that socio-cultural aspects can also shape the perception of a certain risk. 
Globally, the respondents from both groups showed some general knowledge about seismic phenomena but a few gaps were also detected. In general, they make a correct assessment of the seismic risk in their own country. However, the respondents showed a relative lack of contact with the seismic phenomenon, due to the absence of high-magnitude earthquakes or even moderate earthquakes in recent decades. It follows that they had difficulty in recalling seismic episodes in their own countries, while they had less difficulty in indicating earthquakes that have occurred in recent years in other parts of the world. Even so, the earthquake of 1 November 1755 is consistently the most frequently mentioned seismic episode, proving that it continues to be part of the collective awareness of the Portuguese group, while it is virtually ignored by the Spanish group. Likewise, the Portuguese group includes the highest percentage, albeit still low, of respondents who say they have felt an earthquake, claimed to have noticed a seismic episode or even recognize the unpredictability of the seismic phenomenon.

The possibility of earthquake prediction is precisely one of the gaps detected in the geological knowledge of the respondents. Several participants from both groups, but even more often in the Spanish group, supported this thesis. Science and technology have contributed to a better identification of the seismic higher risk zones and the development of earthquake-proof construction techniques (Lima 1994), but the unpredictability of earthquakes continues and can jeopardize the positive effect of scientific and technological knowledge (Geller 1997).

The respondents also had difficulties in differentiating among areas of different seismic risk in Spain or Portugal, since their answers are sometimes not focused on concrete areas, or are too generic. These gaps may be due to their teacher training courses, in which geological knowledge is given scant coverage and not focused on the regional aspects of both countries. Based on the syllabuses consulted, plate tectonics is studied in a global way, ignoring the concrete implications of this theory in the seismicity in Spain and Portugal. Issues related to Disaster Risk Education are also completely ignored in other curricular units not related to Science.

Curiously, in this study, no respondent based the selection of risks on the possibility of their occurrence during the children's time at school. It is true that a number of respondents from both groups selected seismic risk due to the need to know how to act before, during and after an earthquake. But a direct connection with their possible occurrence during school time was never established. Several terrible occurrences could be cited concerning this situation, like the Kashmir earthquake in Pakistan in 2005, in which more than 8000 schools were damaged and over 17000 schoolchildren died in the collapsed schools and over 20000 were injured (Gwee, Shaw, and Takeuchi 2011).

A disturbing study conducted by Augenti et al. (2004) in the Molise region of Italy, after an inspection of approximately 300 schools in primary and secondary education, has concluded that the majority had been built without earthquake proofing. This is particularly troubling, since Italy has a higher seismic risk than Spain or Portugal (Téllez Alarcia 2007). For instance, in Portugal, the refurbishment of over 300 secondary schools started in 2008 and one of its aims was to reinforce the resistance to seismic activity (Proença and Gago 2011). This was certainly an important step but it is unknown whether the same is planned for primary schools. Unfortunately, the seismic standard for the Spanish and Portuguese territories, in which calamities of greater magnitude can happen at intervals of several centuries, may justify a lack of precaution in terms of prevention, such as the use of earthquake-proof construction.

A similar concern is expressed by Wisner et al. (2004), who claim that several hundred million children who live in countries with high seismic activity are at risk when they attend school. At the same time, they found that programmes analyzed from various countries aimed at applying the principles agreed at the Dakar Conference in 2000 to foster a global effort to increase the enrolment of children, commonly known as 'Education for All', made no reference to seismic protection at school. 


\section{Conclusions}

Considering the main differences between the results of the two groups, it seems that seismic risk is perceived as less important in the Spanish group, due to the effects of other natural risks in the recent years, an aspect that seems to have an influence on the options of these participants. Some of the dimensions that affect risk perception mentioned in the introduction section were revealed in the answers of the participants but others were absent, perhaps due to a lack of discussion about these issues during their training courses.

Given the great advance in knowledge it has become increasingly difficult to include on the curriculum all subjects that may be relevant for children's education. Teachers often have to make choices, particularly among subjects that are related to Disaster Risk Education, based on their knowledge and perception of their importance, especially when the curriculum guidelines do not emphasize the need to address these subjects. In this study certain arguments were highlighted to support the need to address seismic risk in primary education and, as seen from the responses of the participants from both countries, some changes must be made at the level of teacher training courses.

Dealing with risk in Science Education started a few decades ago. In fact, Eijkelhof (1986), more than 30 years ago, highlighted this need. But perhaps what is more recent is how the unpredictability of certain natural risks can help to better understand the nature of scientific knowledge, which cannot provide a solution to all our problems due to its limitations (Christensen 2009). Simultaneously, since risk perception is influenced by social, cultural and psychological dimensions, a less compartmentalized approach to Disaster Risk Education is also needed.

Therefore, the curriculum of teachers training courses should be designed with a more interdisciplinary content based on the principles of Disaster Risk Education, as is already the case with Health Education or Environmental Education. Socio-scientific issues in the curriculum have a strong connection with Education for Citizenship and can be an approach with high significance for students, since they deal with real problems. In fact, we also need more contextualized approaches to scientific knowledge, which rarely goes beyond the level of generality in strictly scientific curricular units, especially in teacher training courses for the lower levels of schooling.

Thus, changes must be made in the design of teacher training courses in Portugal and Spain in the near future, and perhaps in other countries with similar seismic features. This will help raise awareness of the need to address seismic risk in schools, but other actions by political and economic authorities are also needed.

\section{Acknowledgments}

We are grateful to the Science Education area in the Faculty of Educational Sciences of the University of Cádiz (Spain) and to the Escola Superior de Educação from Instituto Politécnico de Lisboa (Portugal), for facilitating the access to the classrooms that allowed this research to be carried out.

\section{Disclosure statement}

No potential conflict of interest was reported by the authors.

\section{ORCID}

António Almeida (iD http://orcid.org/0000-0002-3594-1324

Beatriz García Fernández (iD) https://orcid.org/0000-0003-3541-1718

Isilda Rodrigues (iD https://orcid.org/0000-0002-6020-5767 


\section{References}

Aragão, A. 2011. "Prevenção de Riscos na União Europeia: O Dever de Tomar em Consideração a Vulnerabilidade Social Para Uma Proteção Civil Eficaz e Justa. [Risk Prevention in the European Union: The Duty to Take into account Social Vulnerability for Effective and Fair Civil Protection]." Revista Crítica de Ciências Sociais 93:71-93. doi:10.4000/rccs.174.

Augenti, N., E. Cosenza, M. Dolce, G. Manfredi, A. Masi, and L. Samela. 2004. "Performance of School Buildings during the 2002 Molise, Italy, Earthquake." Earthquake Spectra 20(S1):S257-S270. doi:10.1193/1.1769374.

Avouac, J. 2003. "Mountain Building, Erosion, and the Seismic Cycle in the Nepal Himalaya." Advances in Geophysics 46:1-80.

Birkmann, J., K. Von Teichman, T. Welle, M. Gozález, and M. Olabarrieta. 2011. “O Risco Não Percepcionado Para as Zonas Costeiras da Europa: Os Tsunamis e a Vulnerabilidade de Cádis, Espanha. [the Unnoticed Risk for Coastal Zones of Europe: The Tsunamis and the Vulnerability of Cadiz, Spain]." Revista Crítica de Ciências Sociais 93: 129-165. doi: $10.4000 /$ rccs.1368.

Bufe, C., and D. Varnes. 1993. "Predictive Modeling of the Seismic Cycle of the Greater San Francisco Bay Region." Journal of Geophysical Research 98(B6):9871-9883. doi:10.1029/93JB00357.

Burton, C. G., and V. Silva. 2014. Integrated risk modeling within the Global Earthquake Model (GEM): test case application for Portugal. Proceedings of the Second European Conference on Earthquake Engineering and Seismology. Retrieved from: http://www.eaee.org/Media/Default/2ECCES/2ecces_eaee/1626.pdf

Campos Romero, M. L. 1992. El Riesgo de Tsunamis en España. Análisis y Valoración Geográfica. [the Risk of Tsunamis in Spain. Analysis and Geographic Valuation]. Madrid: Instituto Geográfico Nacional.

Carreño Herrero, E. 2005. "La Peligrosidad de Tsunamis en Las Costas Españolas. Simulaciones. [Tsunami Hazard in the Spanish Coasts. Flooding Scenario]." Enseñanza de Las Ciencias de la Tierra: Revista de la Asociación Española Para la Enseñanza de Las Ciencias de la Tierra 13(1):60-64.

Christensen, C. 2009. "Risk and School Science Education." Studies in Science Education 45(2):205-223. doi:10.1080/ 03057260903142293.

Dupuy, J. P. 2006. "Ainda há Catástrofes Naturais? [Are There Still Natural Disasters?]." Análise Social XLI(181): 1181-1193.

Eijkelhof, H. 1986. Dealing with acceptable risk in science education: the case of ionizing radiation, In Ethics and Social Responsibility in Science Education., edited by M. J. Frazer and A. Kornhauser, 189-199. Oxford, UK: Pergamon Press.

Field, A. 2009. Discovering Statistics Using SPSS. London, UK: Sage publications.

Garder, G., and M. Jones. 2011. "Science Instructor's Perceptions of the Risks of Biotecnology: Implications for Science Education." Research in Science Education 41(5):711-738. doi:10.1007/s11165-010-9187-0.

Geller, R. 1997. "Earthquake Prediction: A Critical Review." Geophysical Journal International 131:425-450. doi: 10.1111/j.1365-246X.1997.tb06588.x.

Gonçalves, C. 2004. Incerteza, Gestão e Decisão: O Caso Do Risco Sísmico. [Uncertainty, Management and Decision: The Case of Seismic Risk]. Actas Dos Ateliers Do Vo Congresso Português de Sociologia - Sociedades Contemporâneas: Reflexividade e Acção. Atelier: Modernidade, Incerteza e Risco, 8-13. Retrieved from http://www. aps.pt/cms/docs_prv/docs/DPR4628e84b186ba_1.pdf.

Gregario, L. 2010. Scientific Literacy and Natural Disaster Preparedness. Bangkok: UNESCO.

Gulay, H. 2010. "An Earthquake Education Program with Parent Participation for Preschool Children." Educational Research and Review 5(10):624-630.

Gwee, Q. R., R. Shaw, and Y. Takeuchi. 2011. Disaster Education Policy: Current and Future, In Disaster Education. Community, Environment and Disaster Risk Management, edited by R. Shaw, K. Shiwaku, \& Y. Takeuchi, 23-44. Bingley: Emerald Group Publishing,

Hays, W. 2004. Earthquakes, In International Perspectives on Natural Disasters: Occurrence, Mitigation, and Consequences, edited by J. Stoltman, J. Lidstone, and L. Dechano, 11-36. New York, NY: Springer Science + Business Media

Hosseini, M., and Y. Izadkhah. 2006. "Earthquake Disaster Risk Management Planning in Schools." Disaster Prevention and Management: An International Journal 15(4):649-661. doi:10.1108/09653560610686595.

Instituto Geográfico Nacional - IGN 2017. Los Riesgos en España. [Risks in Spain]. Madrid: Ministerio de Fomento. Retrieved from: https://www.ign.es/espmap/riesgos_bach.htm

Instituto Geográfico Nacional 2015. Catalogo Sismico [Seismic Cathalogue]. Madrid: Ministerio de Fomento, Gobierno de España. Retrieved from: https://www.ign.es/web/resources/docs/IGNCnig/Imagenes_web/Galeria-mapa-mes/ sismicidad-peninsula-iberica-zonas-proximas.jpg

Instituto Geográfico Nacional 2015. Mapa de Peligrosidad Sísmica de España [Seismic Hazard Map of Spain]. Madrid: Ministerio de Fomento, Gobierno de España. Retrieved from: http://www.ign.es/web/mapas-sismicidad

King, D., and Y. Gurtner. 2005. "After the Wave: A Wake up Warning for Australian Coastal Locations." The Australian Journal of Emergency Management 20(1):4-9.

Levy, P., and H. Goldstein. 1984. Tests in Education: A Book of Critical Reviews. London, UK: Academic Press. 
Ley Orgánica 8/2013, de 9 de diciembre, para la Mejora de la Calidad Educativa (LOMCE) 2013, 10 December. [Organic Law 8/2013, of December 9, for the Improvement of Educational Quality]. Boletín Oficial Del Estado (Spain) 295.

Lima, M. 1994. Percepção Do Risco Sísmico: medo e llusões de Controlo. [Perception of Seismic Risk: Fear and Control Illusions]. Tese de Doutoramento Não Publicada. Lisboa: ISCTE.

Lima, M. 2005. Percepção de riscos ambientais. [Perception of environmental risks]. In Contextos Humanos $e$ Psicologia Ambiental, edited by L. Soczka, 203-245. Lisboa: Fundação Calouste Gulbenkian.

Lima, M. 2008. "Tragédia, Risco e Controlo: uma Releitura Psico-Social Dos Testemunhos Do Terramoto de 1755. [Tragedy, Risk and Control: A Psycho-Social Retelling of the 1755 Earthquake Testimonies]." Análise Social XLIII(1):7-28.

Lima, V. V., J. M. Miranda, M. A. Baptista, J. Catalão, M. Gonzalez, L. Otero, M. Olabarrieta, J. A. Álvarez-Gómez, and E. Carreño. 2010. "Impact of a 1755-like Tsunami in Huelva, Spain." Natural Hazards and Earth System Science 10(1):139-148. doi:10.5194/nhess-10-139-2010.

Matias, L., T. Cunha, A. Annunziato, M. Baptista, and F. Carrilho. 2013. "Tsunamigenic Earthquakes in the Gulf of Cadiz: fault Model and Recurrence." Natural Hazards and Earth System Sciences 13(1):1-13. doi:10.5194/nhess-13-1-2013.

Maxwell, K. 2005. O Terramoto de 1755 e a recuperação urbana sob a influência do Marquês de Pombal. [The 1755 earthquake and the urban recovery under the influence of the Marquis of Pombal]. In O Grande Terramoto de Lisboa - Ficar Diferente, edited by H. Buescu and G. Cordeiro, 209-237. Lisboa: Gradiva.

Ministério da Educação 2004. Organização Curricular e Programas Do Ensino Básico - 1. Ciclo.[Curricular Organization and Syllabus of Basic Education - 1st Cycle]. Lisboa: Departamento da Educação Básica.

Miranda, J., and F. Carrilho. $\mathrm{n}$ d. 45 anos do sismo de 28 de fevereiro de 1969. [45 years of the earthquake of February 28, 1969]. http://www.ipma.pt/export/sites/ipma/bin/docs/relatorios/geofisica/rel_sismo-1969.pdf (accessed 24 April 2018).

Morrissey, M. 2007. Curriculum Innovation for Natural Disaster Reduction: Lessons from the Commonwealth Caribbean. In International Perspectives on Natural Disasters: Occurence, Mitigation, and Consequences, edited by J. P. Stoltman, J. Lidstone, and L. M. Dechano, 397-408. Dordrecht: Springer.

Muttarak, R., and W. Lutz. 2014. "Is Education a Key to Reducing Vulnerability to Natural Disasters and Hence Unavoidable Climate Change?." Ecology and Society 19(1):1-8.

National Research Council 2013. Preparing the Next Generation of Earth Scientists: An Examination of Federal Education and Training Programs. Washington, DC: The National Academies Press.

Panić, M., J. Kovačević - Majkić, D. Miljanović, and R. Miletić. 2013. "Importance of Natural Disaster Education - Case Study of the Earthquake near the city of Kraljevo - first results." Journal of the Geographical Institute Jovan Cvijic SASA 63(1):75-88.

Proença, J., and A. Gago. 2011. Seismic Strengthening of School Buildings. Lisbon: Parque Escolar, EPE.

Proteção Civil Portugal 2010. Riscos Naturais em Portugal - Uma Perspectiva da Protecção Civil. [Natural Risks in Portugal - a Civil Protection Perspective]. Lisboa: Autoridade Nacional de Proteçao Civil. Retrieved from: http:// www.ipma.pt/resources.www/docs_pontuais/ocorrencias/2010/newsletter04_pptANPC.pdf

Protección Civil 2013. Riesgos. [Risks]. Madrid: Dirección General de Protección Civil y Emergencias. Retrieved from: http://www.proteccioncivil.es/riesgos

Purcaru, G., and H. Berckhemer. 1982. "Regularity Patterns and Zones of Seismic Potential for Future Large Earthquakes in the Mediterranean Region." Tecronophysics 85(1-2):1-30. doi:10.1016/0040-1951(82)90073-7.

Real Decreto 126/2014, de 28 de Febrero, Por el Que se Establece el Currículo Básico de la Educación Primaria. [The Royal Decree for Minimum Teaching Requirements]. Boletín Oficial Del Estado (Spain) 52 .

Sagoff, M. 1992. Technological risk: A budget of distinctions, In The Environment in Question, edited by D. E. Cooper, and J. A. Palmer, 194-211. London, UK: Routledge.

Saúde, A., E. Costa, J. Fernandes, M. Esteves, M. Amaral, P. Almeida, and T. André. 2015. Referencial de Educação Para o Risco. [Guidelines for Disaster Risk Education]. Lisboa: Ministério de Educação e Ciência.

Shaw, R., Takeuchi, Y. Gwee, Q, and R. Shiwaku, K. 2011. Disaster Education: An Introduction, In Disaster Education. Community, Environment and Disaster Risk Management, edited by R. Shaw, K. Shiwaku, and Y. Takeuchi, 1-2. Bingley: Emerald Group Publishing.

Shiwaku, K. 2009. Essentials of school disaster education: Example from Kobe, Japan, In Disaster Management: Global Challenges and Local Solutions, edited by R. Shaw and R. Krishnamurthy, 321-337. Hyderabad, India: University Press.

Silva, S., M. Romsdorf, L. Matias, P. Terrinha, W. Geissler, and F. Carrilho, and the NEAREST working Group 2010. Seismotectonics of the Gulf of Cadiz: New Insights from Instrumental Seismicity. Resúmenes de la $1^{\text {a }}$ Reunión Ibérica sobre Fallas Activas y Paleosismología, Sigüenza, España. Retrieved from: http://repositorio.Ineg.pt/bitstream/10400.9/1307/1/34469.pdf

Slovic, P. 2001. The Perception of Risk. London, UK: Earthscan.

Tavares, A., J. Mendes, and E. Bastos. 2011. "Percepção Dos Riscos Naturais e Tecnológicos, Confiança Institucional e Preparação Para Situações de Emergência: O Caso de Portugal Continental. [Perception of Natural and Technological Risks, Institutional Trust and Emergency Preparedness: The Case of Mainland Portugal]." Revista Crítica de Ciências Sociais 93:167-193. doi:10.4000/rccs.1380. 
Téllez Alarcia, D. 2007. El impacto del terremoto de Lisboa en España. [The impact of the Lisbon earthquake in Spain]. In O Terramoto de 1755: Impactos Históricos, edited by A. Araújo, J. Cardoso, N. Monteiro, W. Rossa, and J. Serrão, 77-95. Lisboa: Livros Horizonte.

Wisner, B., P. Blaikie, T. Cannon, and I. Davis. 2004. At Risk. Natural Hazards, Peoplés Vulnerability and Disasters. 2nd ed. London, UK. Routledge.

Yeh, H. 2010. "Gender and Age Factors in Tsunami Casualties." Natural Hazards Review 11(1):29-34. doi:10.1061/ (ASCE)1527-6988(2010)11:1(29). 